\title{
The mechanisms of reversible immobilization of fowl spermatozoa at body temperature
}

\author{
K. Ashizawa, S. Maeda and K. Okauchi \\ Laboratory of Animal Reproduction, Faculty of Agriculture, Miyazaki University, \\ Miyazaki 889-21, Japan
}

\begin{abstract}
Summary. Intact fowl spermatozoa became almost immotile at $40^{\circ} \mathrm{C}$, but motility increased significantly at $30^{\circ} \mathrm{C}$. The oxygen consumption at both temperatures was $8-11 \mu \mathrm{O}_{2} / 10^{10}$ spermatozoa $\cdot \mathrm{min}^{-1}$. The ATP concentration at $40^{\circ} \mathrm{C}$ was higher than that at $30^{\circ} \mathrm{C}$ but ADP concentration at $30^{\circ} \mathrm{C}$ was higher than that at $40^{\circ} \mathrm{C}$. Consequently, the ATP/ADP ratio at $30^{\circ} \mathrm{C}(1.9-2.2)$ increased to $3.5-3.7$ at $40^{\circ} \mathrm{C}$. The motility of intact spermatozoa at $40^{\circ} \mathrm{C}$ was effectively restored by $2 \mathrm{~mm}-$ $\mathrm{Ca}^{2+}, 10 \%$ seminal plasma and $10 \%$ peritoneal fluid taken at the time of ovulation. In contrast, these effectors did not restore the motility of demembranated spermatozoa at $40^{\circ} \mathrm{C}$. Motility of demembranated spermatozoa was restored at $30^{\circ} \mathrm{C}$. These results suggest that the immobilization of fowl spermatozoa at $40^{\circ} \mathrm{C}$ occurs due to a decrease in flagellar dynein ATPase activity. Furthermore, the action of effectors for motility such as $\mathrm{Ca}^{2+}$ may not be directly on the axoneme, but mediated by solubilized substances which have been removed by demembranation of the spermatozoa.
\end{abstract}

Keywords: spermatozoa; motility; immobilization; temperature; fowl

\section{Introduction}

Generally, both vigour of motility and metabolic activity of mammalian spermatozoa increase with rising temperature. Maximum metabolic activity of spermatozoa occurs between 40 and $47^{\circ} \mathrm{C}$ (Beck \& Salisbury, 1943; Freund et al., 1959; Salisbury \& Lodge, 1962). With fowl spermatozoa, in contrast, it has been reported that most synthetic diluents preserve the vigour of motility at room temperature but inhibit it at $40-41^{\circ} \mathrm{C}$, normal body temperature (Munro, 1938; Nevo \& Schindler, 1968; Ashizawa \& Nishiyama, 1978; Takeda, 1982a; Wishart \& Ashizawa, 1987). The immobilization is not permanent and movement resumes when the temperature is lowered to room temperature or calcium, caffeine, seminal plasma and female peritoneal fluid taken at the time of ovulation are added (Munro, 1938; Nevo \& Schindler, 1968; Ashizawa et al., 1976; Ashizawa \& Nishiyama, 1978; Takeda, 1982a; Ashizawa \& Okauchi, 1984; Ashizawa \& Wishart, 1986, 1987; Wishart \& Ashizawa, 1987). The motility-stimulating factors in seminal plasma and peritoneal fluid are believed to be calcium and a low molecular weight $(\sim 200)$, dialysable substance (Ashizawa \& Wishart, 1986, 1987). However, the mechanisms for the immobilization and restoration of fowl sperm motility remain unknown.

It has been suggested that demembranated fowl spermatozoa (Ashizawa et al., 1989) may be useful to clarify the mechanisms of the reversible, temperature-dependent immobilization of fowl spermatozoa. This study was undertaken to investigate this phenomenon. 


\section{Materials and Methods}

Animals and semen collection. Male fowl (White Leghorn, Babcock strain) were obtained from Akagi Poultry Breeding Farm, Miyazaki, Japan. They were caged individually, given $14 \mathrm{~h}$ light $/ 24 \mathrm{~h}$ and fed a commercial breeders ration ad libitum. Semen was collected by the method of Bogdonoff \& Shaffner (1954).

Preparation of spermatozoa. Samples of semen pooled from 4-6 different males were diluted approximately 10-fold in $150 \mathrm{~mm}-\mathrm{NaCl}$ with $20 \mathrm{~mm}$-TES ( $N$-Tris-[hydroxymethyl]-methyl-2-aminoethanesulphonic acid) at $\mathrm{pH} 7.4$ and centrifuged at $700 \mathrm{~g}$ for $13 \mathrm{~min}$ at room temperature $\left(20-25^{\circ} \mathrm{C}\right)$. The washed spermatozoa were reconstituted in the same buffer to give a final concentration of $\sim \mathrm{I} \times 10^{9}$ cells $/ \mathrm{ml}$. Samples of $3-4 \mathrm{ml}$ were poured into $30-\mathrm{ml}$ Erlenmeyer flasks with a screw cap.

Measurement of motility, oxygen consumption and ATP and ADP concentrations of intact spermatozoa at $30^{\circ} \mathrm{C}$ and $40^{\circ} \mathrm{C}$. The preparations were incubated aerobically in a shaking water bath at $30^{\circ} \mathrm{C}$ for $15 \mathrm{~min}$, and then transferred to another shaking water bath and incubated at $40^{\circ} \mathrm{C}$ for $15 \mathrm{~min}$. After that, they were re-incubated at $30^{\circ} \mathrm{C}$ for $15 \mathrm{~min}$. Finally, they were moved to $40^{\circ} \mathrm{C}$ again and incubated for $15 \mathrm{~min}$. Overall, the samples were incubated for $60 \mathrm{~min}$ at $30^{\circ} \mathrm{C}$ and $40^{\circ} \mathrm{C}$, changing every $15 \mathrm{~min}$. During incubation, sperm motility, oxygen consumption and ATP and ADP concentration were measured every $5 \mathrm{~min}$ at each temperature.

Sperm motility was assayed as described by Wishart \& Ross (1985), using a double-beam spectrophotometer (Shimadzu, Model UV-150-02, Kyoto, Japan), but substituting the NaCl/TES buffer described above. The constant, $\%(\Delta \mathrm{OD})_{\mathrm{m}}$, which correlates with the percentage of motile spermatozoa (Wishart \& Ross, 1985), was used to describe 'motility'. Numbers of spermatozoa were established from the constant $\mathrm{OD}_{\mathrm{m}}$.

Oxygen consumption of spermatozoa was determined polarographically with a Clark electrode by the method of Kielley (1963), using a YSI model 53 biological oxygen monitor (Yellow Springs Instrument Co., Inc., Yellow Springs, Ohio, USA). The rate of oxygen consumption was expressed in terms of $\mu 1 \mathrm{O}_{2}$ consumption/10 spermatozoa $\cdot \min ^{-1}$.

ATP concentration in spermatozoa was assayed in a boiled extract (Wishart, 1982). ADP concentrations were assayed by the method of Kimmich et al. (1975) and ATP/ADP ratios were calculated.

Motility of intact and demembranated spermatozoa incubated with various effectors at $30^{\circ} \mathrm{C}$ and $40^{\circ} \mathrm{C}$. Intact spermatozoa incubated aerobically for $15 \mathrm{~min}$ at $40^{\circ} \mathrm{C}$ were demembranated at $40^{\circ} \mathrm{C}$ according to the method described previously (Ashizawa et al., 1989). The extraction medium used consisted of $0 \cdot 1 \%$ Triton X-100, $0 \cdot 2 \mathrm{M}$-sucrose, $25 \mathrm{~mm}$-potassium glutamate, $1 \mathrm{~mm}-\mathrm{MgSO}_{4}, 1 \mathrm{~mm}$-dithiothreitol and $20 \mathrm{~mm}$-Tris- $\mathrm{HCl}$ buffer (pH 7.9). The reactivation medium consisted of $0.5 \mathrm{mM}$-ATP, $0.2 \mathrm{M}$-sucrose, $25 \mathrm{~mm}$-potassium glutamate, $\mathrm{I} .5 \mathrm{~mm}-\mathrm{MgSO}_{4}$, I mM-dithiothreitol and $20 \mathrm{~mm}$-Tris- $\mathrm{HCl}$ buffer ( $\mathrm{pH} 7 \cdot 9$ ). To examine the effectors for motility, various concentrations of $\mathrm{CaCl}_{2}, \mathrm{MgSO}_{4}$, seminal plasma and peritoneal fluid of hens taken at the time of ovulation were added to the reactivation medium. Seminal plasma and peritoneal fluid were prepared by the methods of Ashizawa \& Wishart (1986, 1987). The suspension of demembranated spermatozoa was placed on a microscope slide chamber, and the motility of spermatozoa was recorded by videomicroscopy at $40^{\circ} \mathrm{C}$ on the thermostatically-controlled warm plate. The percentages of motile spermatozoa were measured by the method of Katz \& Overstreet (1981). After that, the same samples were cooled to $30^{\circ} \mathrm{C}$ and the motility was observed again. The motility of intact spermatozoa which were suspended in the extraction medium without Triton X-100 and transferred to the reactivation medium was also measured by the same method. All data were subjected to statistical analysis by the method of Duncan (1955).

\section{Results}

Effects of temperatures on the motility, oxygen consumption, ATP and ADP concentrations of intact fowl spermatozoa

Sperm motility was markedly affected by the temperature (Fig. 1a). During the first incubation at $30^{\circ} \mathrm{C}$, spermatozoa showed $\sim 50 \%$ motility, and even after a second incubation at $30^{\circ} \mathrm{C}, \sim 40 \%$ motility was obtained. In contrast, spermatozoa lost motility quickly at $40^{\circ} \mathrm{C}$.

The oxygen consumptions at both temperatures were $8 \cdot 2-11 \cdot 0 \mu \mathrm{O}_{2} / 10^{10}$ spermatozoa $\cdot \mathrm{min}^{-1}$ (Fig. 1b). There was no significant difference between the two temperatures $(P>0 \cdot 01)$.

The ATP content (nmol $/ 10^{9}$ spermatozoa) was higher at $40^{\circ} \mathrm{C}(47 \cdot 8-50 \cdot 1)$ than at $30^{\circ} \mathrm{C}(38 \cdot 3-$ 43.3) and the ADP content (nmol/ $10^{9}$ spermatozoa) was lower at $40^{\circ} \mathrm{C}(13 \cdot 7-14.8)$ than at $30^{\circ} \mathrm{C}$ (19.1-21.9) (Fig. 2). Consequently, the ATP/ADP ratio at $30^{\circ} \mathrm{C}(1 \cdot 9-2 \cdot 2)$ increased significantly to 3.5-3.7 at $40^{\circ} \mathrm{C}(P<0.01)$ (Fig. 2). 


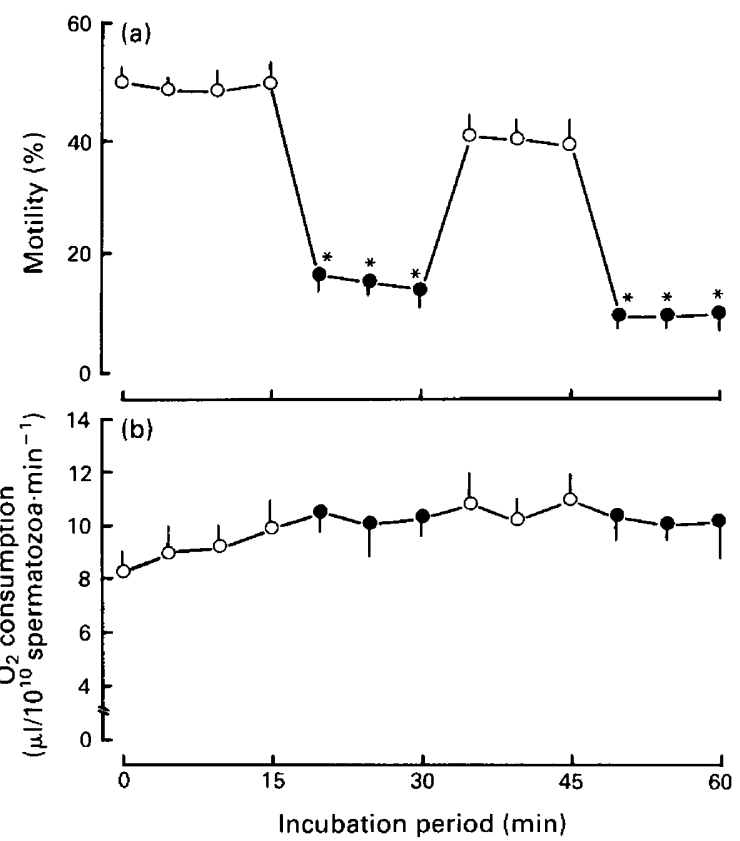

Fig. 1. The motility (a) and oxygen consumption (b) of intact fowl spermatozoa during incubation at $30^{\circ} \mathrm{C}(\mathrm{O})$ and $40^{\circ} \mathrm{C}(\mathbf{O})$. Each point represents the mean $( \pm$ s.e.m.) of 5 samples of spermatozoa. ${ }^{*} P<0.01$ compared with 0 min value.

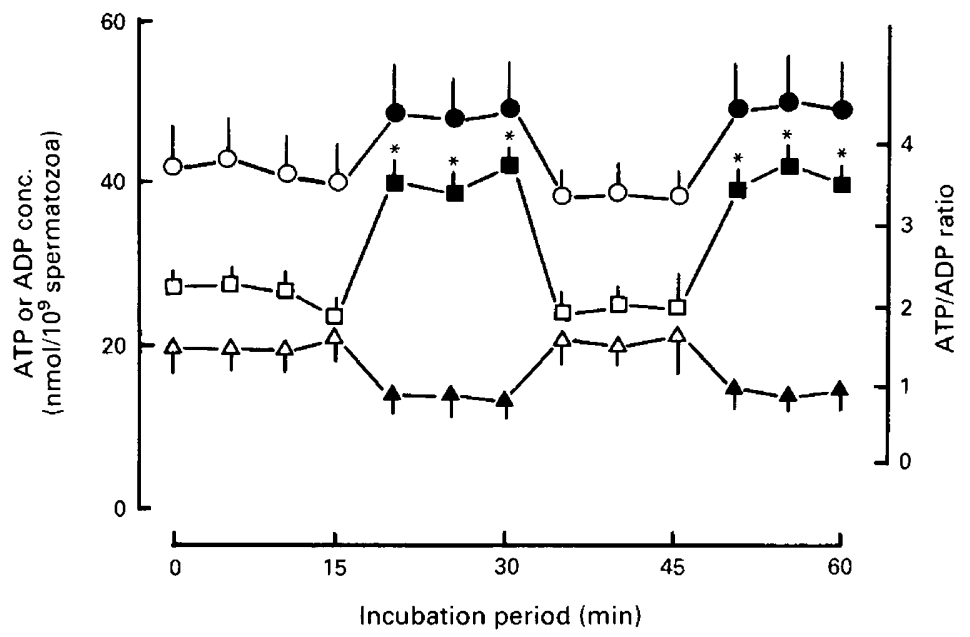

Fig. 2. ATP $\left(O_{-} \boldsymbol{O}^{\prime}\right.$ ) and ADP $(\triangle-\Delta)$ concentrations and ATP/ADP ratio ( $\left.\square-\square\right)$ of intact fowl spermatozoa during incubation at $30^{\circ} \mathrm{C}(O, \triangle, \square)$ and $40^{\circ} \mathrm{C}(\odot, \Delta, \boldsymbol{a})$. Each point represents the mean ( \pm s.e.m.) of 5 samples of spermatozoa. ${ }^{*} P<0.01$ compared with 0 min value. 
Effects of various effectors on the motility of intact and demembranated fowl spermatozoa at $40^{\circ} \mathrm{C}$ and $30^{\circ} \mathrm{C}$

Motility became vigorous even at $40^{\circ} \mathrm{C}$ when intact spermatozoa were suspended in fluids to which had been added $2 \mathrm{mM}-\mathrm{Ca}^{2+}, 10 \%$ seminal plasma or $10 \%$ peritoneal fluid (Table 1 ). In contrast, the addition of $2 \mathrm{~mm}-\mathrm{Mg}^{2+}$ was not effective. Motility of these samples of spermatozoa was restored at $30^{\circ} \mathrm{C}$. However, at $30^{\circ} \mathrm{C}$, no significant stimulation of motility by calcium, seminal plasma and peritoneal fluid was observed. These results were similar to those reported by Wishart \& Ashizawa (1987). In contrast, these substances had no effect with the demembranated spermatozoa at $40^{\circ} \mathrm{C}$ (Table 1). In addition, cAMP was not effective. Motility of all samples of spermatozoa was restored at $30^{\circ} \mathrm{C}$, although to different levels, depending on the concentrations of effectors, e.g. high concentrations of calcium ( $10 \mathrm{~mm})$ inhibited motility.

Table 1. Effects of various substances on the motility of intact or demembranated fowl spermatozoa at $40^{\circ} \mathrm{C}$ and $30^{\circ} \mathrm{C}$

\begin{tabular}{|c|c|c|c|}
\hline \multirow[b]{2}{*}{ Spermatozoa } & \multirow[b]{2}{*}{ Substances (conc.) } & \multicolumn{2}{|c|}{ Motility (\%) } \\
\hline & & $40^{\circ} \mathrm{C}$ & $30^{\circ} \mathrm{C}$ \\
\hline Intact & $\begin{array}{l}\text { None (control) } \\
\mathrm{Ca}^{2+}(2 \mathrm{~mm}) \\
\mathrm{Mg}^{2+}(2 \mathrm{~mm}) \\
\text { Seminal plasma }(10 \%) \\
\text { Peritoneal fluid }(10 \%)\end{array}$ & $\begin{array}{r}8 \cdot 7 \pm 0 \cdot 6^{\mathrm{a}} \\
68 \cdot 2 \pm 2 \cdot 3^{\mathrm{b}} \\
9 \cdot 0 \pm 1 \cdot 2^{\mathrm{a}} \\
71 \cdot 8 \pm 3 \cdot 2^{\mathrm{b}} \\
72 \cdot 4 \pm 4 \cdot 1^{\mathrm{b}}\end{array}$ & $\begin{array}{l}62 \cdot 5 \pm 3 \cdot 2^{\mathrm{a}} \\
70 \cdot 3 \pm 2 \cdot 4^{\mathrm{a}} \\
63 \cdot 4 \pm 4 \cdot 1^{\mathrm{a}} \\
70 \cdot 6 \pm 4 \cdot 8^{\mathrm{a}} \\
71 \cdot 7 \pm 3 \cdot 2^{\mathrm{a}}\end{array}$ \\
\hline Demembranated & $\begin{array}{c}\text { None (control) } \\
\mathrm{Ca}^{2+}(0 \cdot 1 \mathrm{mM}) \\
(1 \mathrm{~mm}) \\
(10 \mathrm{mM}) \\
\mathrm{Ca}^{2+}(1 \mathrm{mM})+\text { cAMP }(10 \mu \mathrm{M}) \\
\mathrm{Mg}^{2+}(0 \cdot 1 \mathrm{mM}) \\
(1 \mathrm{mM}) \\
(10 \mathrm{mM}) \\
\mathrm{Mg}^{2+}(1 \mathrm{mM})+\text { cAMP }(10 \mu \mathrm{M}) \\
\text { Seminal plasma }(0 \cdot 1 \%) \\
(1 \%) \\
(10 \%) \\
\text { Peritoneal fluid }(0 \cdot 1 \%) \\
(1 \%) \\
(10 \%)\end{array}$ & $\begin{array}{l}0 \\
0 \\
0 \\
0 \\
0 \\
0 \\
0 \\
0 \\
0 \\
0 \\
0 \\
0 \\
0 \\
0 \\
0\end{array}$ & $\begin{array}{l}49 \cdot 4 \pm 3 \cdot 0^{\mathrm{a}} \\
42 \cdot 6 \pm 5 \cdot 0^{\mathrm{ab}} \\
32 \cdot 3 \pm 4 \cdot 6^{\mathrm{bc}} \\
19 \cdot 0 \pm 4 \cdot 0^{\mathrm{d}} \\
35 \cdot 4 \pm 4 \cdot 0^{\mathrm{bc}} \\
46 \cdot 9 \pm 3 \cdot 5^{\mathrm{a}} \\
39 \cdot 1 \pm 4 \cdot 3^{\mathrm{ab}} \\
24 \cdot 1 \pm 3 \cdot 6^{\mathrm{cd}} \\
58 \cdot 3 \pm 2 \cdot 3^{\mathrm{a}} \\
43 \cdot 9 \pm 3 \cdot 4^{\mathrm{ab}} \\
56 \cdot 6 \pm 3 \cdot 6^{\mathrm{a}} \\
62 \cdot 7 \pm 6 \cdot 6^{\mathrm{a}} \\
39 \cdot 1 \pm 3 \cdot 5^{\mathrm{ab}} \\
44 \cdot 8 \pm 7 \cdot 0^{\mathrm{ab}} \\
58 \cdot 2 \pm 5 \cdot 7^{\mathrm{a}}\end{array}$ \\
\hline
\end{tabular}

Each figure represents the mean ( \pm s.e.m.) motility of 5 samples of spermatozoa.

Within columns and sperm preparation type, values with different superscripts differ significantly $\left(P<0^{-01}\right)$ from each other.

\section{Discussion}

The present results showed that, as in previous studies (Ashizawa \& Nishiyama, 1978; Takeda, $1982 \mathrm{~b}$; Wishart, 1984), the oxygen consumption of intact spermatozoa did not increase at $40^{\circ} \mathrm{C}$ compared with that $30^{\circ} \mathrm{C}$. Therefore, it is assumed that the amounts of ATP production by respiration were similar at both temperatures. Nevertheless, the ATP/ADP ratio at $40^{\circ} \mathrm{C}$ was about 1.8 -fold higher than that at $30^{\circ} \mathrm{C}$ (Fig. 2). In addition, the demembranated spermatozoa were completely quiescent at $40^{\circ} \mathrm{C}$ in spite of containing a high concentration of ATP in the reactivation medium, and their motility was restored at $30^{\circ} \mathrm{C}$. It is well known that flagellar movement of 
spermatozoa is based on the active sliding of microtubules as a result of ATP hydrolysis of dynein ATPase (for reviews, see Satir, 1979; Warner \& Mitchell, 1980). Therefore, it is possible that for fowl spermatozoa activity for ATP hydrolysis to ADP is lower at $40^{\circ} \mathrm{C}$ than at $30^{\circ} \mathrm{C}$. That is, fowl spermatozoa might be quiescent due to a decrease in flagellar dynein ATPase activity, although the effects of temperature on the activity of dynein ATPase of fowl spermatozoa were not measured in this experiment. Further study is therefore needed to examine the difference of dynein ATPase activity of spermatozoa from fowl and other species.

Motility became vigorous even at $40^{\circ} \mathrm{C}$ when intact fowl spermatozoa were suspended in fluid to which calcium, seminal plasma or peritoneal fluid had been added (Table 1). These results were similar to those reported previously (Ashizawa \& Wishart, 1986, 1987; Wishart \& Ashizawa, 1987). In contrast, these were not effective with the demembranated spermatozoa at $40^{\circ} \mathrm{C}$. Cyclic AMP also did not affect motility (Table 1). The spermatozoa did not degenerate due to the high temperature treatment $\left(40^{\circ} \mathrm{C}\right)$ during demembranation, because motility of the same samples of spermatozoa was restored at $30^{\circ} \mathrm{C}$. From these results, we suggest that the action of substances such as calcium that affect motility is not directly on the axoneme, but is mediated by the solubilized substances such as membrane-associated enzymes which have been removed by the demembranation of the spermatozoa.

We thank Dr M. Morisawa, Tokyo University and Dr K. Ishida, Teikyo University, Japan, for skilful technical advice; and Mr O. Ravie, AFRC Institute of Animal Physiology \& Genetics Research, Edinburgh Research Station, UK, for kindly reading the manuscript. This study was supported by a grant from the Ministry of Education, Science and Culture, Japan (No. 62760226).

\section{References}

Ashizawa, K. \& Nishiyama, H. (1978) Effects of temperature on the vigour of motility, oxygen consumption and duration of motility of fowl spermatozoa under aerobic conditions. Jpn. Poult. Sci. 15, 264266.

Ashizawa, K. \& Okauchi, K. (1984) Stimulation of sperm motility and oxygen consumption of fowl spermatozoa by a low molecular weight fraction of seminal plasma. J. Reprod. Fert. 71, 593-598.

Ashizawa, K. \& Wishart, G.J. (1986) Fowl sperm motility stimulating factor(s) from seminal plasma and female peritoneal fluid taken at the time of ovulation. Develop. Growth Differ. 28, Suppl. 85, Abstr.

Ashizawa, K. \& Wishart, G.J. (1987) Resolution of the sperm motility-stimulating principle of fowl seminal plasma into $\mathrm{Ca}^{2+}$ and an unidentified low molecular weight factor. J. Reprod. Fert. 81, 495-499.

Ashizawa, K., Nishiyama, H. \& Nagae, T. (1976) Effects of oviducal cells on the survival and fertilizing ability of fowl spermatozoa. J. Reprod. Fert. 47, 305-311.

Ashizawa, K., Suzuki, Y. \& Okauchi, K. (1989) Flagellar movement in demembranated preparations of ejaculated fowl spermatozoa. J. Reprod. Fert. 86, 263-270.

Beck, G.H. \& Salisbury, G.W. (1943) Rapid methods for estimating the quality of bull semen. J. Dairy Sci. 26, $483-494$.

Bogdonoff, P.D., Jr \& Shaffiner, C.S. (1954) The effect of $\mathrm{pH}$ on in vitro survival, metabolic activity, and fertilizing capacity of chicken semen. Poult. Sci. 33, $665-669$.

Duncan, D.B. (1955) Multiple range and multiple F tests. Biometrics 11, 1-42.

Freund, M., Mixner, J.P. \& Mather, R.E. (1959) Bovine semen metabolism. V. Influence of incubation temperature on certain measures of fructolysis. $J$. Dairy Sci. 42, 79-82.

Katz, D.F. \& Overstreet, J.W. (1981) Sperm motility assessment by videomicrography. Fert. Steril. 35, 188-193.

Kielley, W.W. (1963) Preparation and assay of phosphorylating submitochondrial particles: sonicated mitochondria. Methods Enzymol. 6, 272-277.

Kimmich, G.A., Randles, J. \& Brand, J.S. (1975) Assay of picomole amounts of ATP, ADP, and AMP using the luciferase enzyme system. Analyt. Biochem. 69, 187-206.

Munro, S.S. (1938) Fowl sperm immobilization by a temperature-media interaction and its biological significance. Q. Jl exp. Physiol. 27, 281-287.

Nevo, A.C. \& Schindler, H. (1968) Reversible inactivation of cock spermatozoa by temperature. Proc. 6th Int. Congr. Anim. Reprod. \& A.I., Paris, Vol. II, $1637-1640$.

Salisbury, G.W. \& Lodge, J.R. (1962) Metabolism of spermatozoa. Adv. Enzymol. 24, 35-104.

Satir, P. (1979) Basis of flagellar motility in spermatozoa: current status. In The Spermatozoon: Maturation, Motility, Surface Properties and Comparative Aspects, pp. 81-90. Eds D. W. Fawcett \& J. M. Bedford. Urban \& Schwarzenberg, Inc., Baltimore.

Takeda, A. (1982a) Studies on reversible inactivation of cock spermatozoa by temperature. I. Effects of several factors on reversible inactivation. Jpn. Poult. Sci. 19, 26-36.

Takeda, A. (1982b) Studies on reversible inactivation of 
cock spermatozoa by temperature. II. Effects of reversible inactivation on $\mathrm{O}_{2}$ consumption and storage of cock spermatozoa. Jpn. Poult. Sci. 19, 135-139.

Warner, F.D. \& Mitchell, D.R. (1980) Dynein: the mechanochemical coupling adenosine triphosphatase of microtubule-based sliding filament mechanisms. Int. Rev. Cytol. 66, 1-43.

Wishart, G.J. (1982) Maintenance of ATP concentrations in and of fertilizing ability of fowl and turkey spermatozoa in vitro. J. Reprod. Fert. 66, 457-462.
Wishart, G.J. (1984) Metabolism of fowl and turkey spermatozoa at low temperatures. J. Reprod. Fert. 70, 145-149.

Wishart, G.J. \& Ashizawa, K. (1987) Regulation of motility of fowl spermatozoa by calcium and cAMP. $J$. Reprod. Fert. 80, 607-611.

Wishart, G.J. \& Ross, F.H. (1985) Characterisation of a spectrophotometric technique for the estimation of fowl and turkey sperm motility. Gamete Res. 11, $169-178$.

Received 30 August 1988 